\title{
The measurement of iron-binding capacity in serum and purified transferrin with the aid of chemical affinity chromatography
}

\author{
W. N. M. RAMSAY \\ From the Veterinary Unit, Department of Biochemistry, University of Edinburgh, Edinburgh
}

SYNOPSIS In a new method for the estimation of transferrin by iron-binding capacity iron is added as the tartrate in $\mathrm{NaCl}$ with about $10 \mathrm{mM}$ bicarbonate. The excess iron is removed by passage through DEAE-Sephadex A-50 previously treated with the iron chelator disodium catechol-3,5-disulphonate. The iron remaining bound to transferrin is measured without protein precipitation by the use of ferrozine. The method is applicable to fresh, frozen, or lyophilized serum, purified transferrin, and some quality control preparations. Validation experiments confirm that transferrin in serum and in pure solution is saturated with iron and give some evidence of specificity. The possible use of commercially available transferrin preparations as analytical reference standards is discussed.

Current methods for the measurement of serum ironbinding capacity lack reproducibility (Dixon, 1973: Leggate and Crooks, 1972; Betts and Stuart, 1973; Fraser, 1973), especially when lyophilized serum is analysed (Bothwell, Conrad, Cook, Crosby, Fielding, Hallberg, Izak, Layrisse, and Ramsay, 1972). The widely used magnesium carbonate method (Ramsay, 1957 ) is not fully specific for transferrin (van der Heul, van Eijk, Wiltink, and Leijnse, 1972; Ramsay, 1973) and requires $2 \mathrm{ml}$ serum.

This paper describes a method of improved sensitivity which is not affected by freezing or lyophilization and storage of serum for two months. Some quality control sera and purified transferrin can be analysed. Non-transferrin iron detected by the methods of Ramsay (1973) is virtually absent, and evidence is given that the transferrin present is saturated with iron.

The method depends on the familiar principle of adding excess iron and removing that thought not to be bound to transferrin. Measurement of the iron retained gives the total iron-binding capacity (TIBC). The saturating iron solution contains tartrate, which complexes with iron and permits the addition of $\mathrm{NaHCO}_{3}$ to $\mathrm{pH} 7-8$. Inclusion of ${ }^{59} \mathrm{Fe}$ allows the estimation of unsaturated iron-binding capacity (UIBC). In serum iron estimation the inititial treatment with iron is omitted.

Non-transferrin iron is removed in a small column Received for publication 18 November 1974. of DEAE-Sephadex A-50 (Ramsay, 1973), pre viously treated with disodium catechol-3,5-disulph\& nate (Tiron, CDS). This reagent adheres to DEAESephadex through the sulphonate ions while retain- ٌ ing its property of chelating with iron. Early workers $\stackrel{\square}{\stackrel{2}{2}}$ (Johnson, 1964) used CDS to estimate $\mathrm{Fe}^{3+}$, but $\overrightarrow{\vec{A}}$ it was found in preliminary experiments that in $\frac{3}{3}$ alkaline solution $\mathrm{Fe}^{2+}$ reacts equally well, even in an atmosphere of argon. Iron is determined spectrophotometrically in the eluate after the addition of 3 (2-pyridyl)-5,6-bis (sodium 4-phenyl sulphonate)1,2,4-triazine (Ferrozine; Stookey, 1970) and ascor- $\frac{5}{3}$ bic acid (Carter, 1971).

Measurements of TIBC on purified transferrin are related to $E_{280}$ rather than to weight because most protein preparations contain small amounts of $\frac{\circ}{5}$ water, salts, and other contaminants. The experi- $\frac{D}{O}$ mental values of absorbance and TIBC are used to calculate the absorptivity of a solution of TIBC $=$ N $2 \mathrm{~mol} / \mathrm{l}$. This function, termed $\epsilon^{\prime}$ for the purposes of this paper, should be equal to the molar absorp- $N$ tivity $\epsilon$ calculated from the molecular weight of $\omega$ transferrin and the specific absorbance $\mathrm{E}^{1 \%} \mathrm{~cm}$. 웅 Recent determinations of the molecular weight $\stackrel{\circ}{\circ}$ (Roberts, Makey, and Seal, 1966; Greene and $\Phi$ Feeney, 1968; Mann, Fish, Cox, and Tanford, + 1968; Palmour and Sutton, 1971; Charlwood, $\frac{T}{-}$ 1971) indicate a value close to 77000 daltons. $\frac{P}{D}$

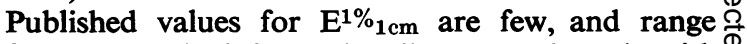

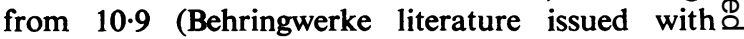


immunological standard transferrin) to 11.9 (Roberts et al 1966). It is therefore not possible to give an exact value for $\epsilon$, but limits of approximately 84000 to 92000 can be set. Some of the reported variations in $\mathrm{E}_{\mathrm{lcm}}^{1 \%}$ may result from overlooking the fact that $\mathrm{E}_{280}$ for $\mathrm{Fe}_{2}$-transferrin is about $25 \%$ higher than the value for apotransferrin. Preliminary experiments showed that in the range of conditions used in this work neither buffer composition nor pH affects $E_{280}$. Bates and Schlabach (1973) used a similar constant which recalculates to $\epsilon=85000$ and is apparently equivalent to $E_{\mathrm{lcm}}^{1 \%}$ $=11 \cdot 04$.

\section{Iron-binding Capacity Method}

Where available, reagents of Analar or similar quality should be used. Disodium catechol-3,5disulphonate (Hopkin and Williams) varies in quality and only pure white finely crystalline batches should be used. Ferrozine is purchased from Ralph Emanuel Ltd. Three transferrin preparations have been studied: human transferrin, substantially iron free (Sigma), iron-free human transferrin (Behringwerke, Hoechst Pharmaceuticals Ltd), and standard human transferrin for immunological analysis (Behringwerke; preweighed $1 \mathrm{mg}$ ampoules). Quality control sera were reconstituted according to the manufacturer's instructions.

Radioactivity is assayed in a Gamma guard 150 counter (Tracerlab (GB) Ltd). Electrophoresis is conducted in $7.5 \%$ polyacrylamide gel in tris-glycine buffer, $\mathrm{pH} 8 \cdot 5$. Gels stained with naphthalene black are scanned at $600 \mathrm{~nm}$ in a Gilford scanner. The spectrophotometer used (Pye-Unicam SP1800B) is calibrated with $\mathrm{K}_{2} \mathrm{Cr}_{2} \mathrm{O}_{7}$ (Rand, 1969), since absolute absorbance values are required for calculating $\epsilon^{\prime}$.

\section{REAGENTS}

The following reagents are required:

\section{$\mathrm{NaCl}-\mathrm{NaHCO} \mathrm{H}_{3}$}

Aqueous solution containing $\mathrm{NaCl}(0.14 \mathrm{~mol} / \mathrm{l})$ and $\mathrm{NaHCO}_{3}(0.02 \mathrm{~mol} / \mathrm{l})$.

\section{Saturating iron solution, $0.75 \mathrm{mmol} / \mathrm{l}$}

On the day of use, mix $0.5 \mathrm{ml}$ ferric chloride $(3 \mathrm{mmol} / \mathrm{l}$ in $\mathrm{HCl}, 20 \mathrm{mmol} / \mathrm{l})$ with $0.1 \mathrm{ml}$ ammonium (+)-tartrate $(1 \mathrm{~mol} / \mathrm{l})$ and add $1.4 \mathrm{ml} \mathrm{NaCl}-\mathrm{NaHCO}_{3}$. The stock solutions are stable indefinitely. For UIBC measurements add ${ }^{59} \mathrm{FeCl}_{3}$ in $\mathrm{HCl}, 20 \mathrm{mmol} / 1$ $(<0.1 \mathrm{ml})$ before the $\mathrm{NaCl}-\mathrm{NaHCO}_{3}$.

\section{Disodium catechol-3,5-disulphonate}

A stock solution of disodium catechol disulphonate
(20 $\mathrm{mmol} / 1$ in water, stable at 4 for one week) is diluted with 9 volumes $\mathrm{NaCl}-\mathrm{NaHCO}_{3}$ immediately before use.

\section{Standard iron solution, $20 \mu \mathrm{mol} / \mathrm{l}$}

Prepare by dilution of a stock solution one hundred times more concentrated, containing $\mathrm{FeSO}_{4}$. $\left(\mathrm{NH}_{4}\right)_{2}$ $\mathrm{SO}_{4} .6 \mathrm{H}_{2} \mathrm{O}, 0.784 \mathrm{~g}$ in $11 \mathrm{HCL}, 2 \mathrm{~mol} / \mathrm{l}$. Oxidation during storage is harmless and both solutions are stable.

\section{Ferrozine, $8 \mathrm{mmol} / \mathrm{l}$ in acetate buffer with ascorbic} acid, $0.1 \mathrm{~mol} / \mathrm{l}$

Dissolve $23 \mathrm{mg}$ ferrozine and $88 \mathrm{mg}$ ascorbic acid in $5 \mathrm{ml}$ acetate buffer (acetic acid $2.4 \mathrm{~mol} / \mathrm{l}$, sodium acetate $0.8 \mathrm{~mol} / \mathrm{l})$. The solution is stable for 10 days at 4 .

\section{DEAE-Sephadex A-50}

The ion exchanger ( $4 \mathrm{~g})$ is thoroughly mixed with $\mathrm{NaCl}-\mathrm{NaHCO}_{3}$ in a measuring cylinder $(250 \mathrm{ml})$ and the gel is allowed to settle. The supernatant is discarded, replaced with fresh $\mathrm{NaCl}-\mathrm{NaHCO}_{3}$, and the process repeated six times to ensure equilibration of the DEAE-Sephadex with the salt solution. The suspension is finally made up to about 1.8 times the volume of the settled ion exchanger.

DEAE-Sephadex columns are supported on acidwashed glass paper discs in $1 \mathrm{ml}$ disposable syringe barrels (Gillette Scimitar). Solutions are introduced without the formation of air locks by the use of extensions to disposable tips for a spring-loaded pipetter adjustable between $0.2 \mathrm{ml}$ and $1 \mathrm{ml}$ (Finnpipette). Eight $\mathrm{cm}$ extensions of polyvinyl tubing (Wright Scientific Ltd; $1.5 \mathrm{~mm}$ id) are needed for filling columns, $2.5 \mathrm{~cm}$ for adding serum and reagents. The appropriate settings for the pipette were found by gravimetric calibration to be close to those for unmodified tips, and delivery slowly executed was highly reproducible with the type of plastic tubing selected.

Immediately after thorough mixing, DEAESephadex suspension $(1.0 \mathrm{ml})$ is pipetted into a prepared syringe barrel by placing the tip of the extended pipette close to the base and withdrawing it smoothly as delivery proceeds. After the excess liquid has drained from the column, CDS in $\mathrm{NaCl}-\mathrm{NaHCO}_{3}(0.25 \mathrm{ml})$ is added, followed by sufficient DEAE-Sephadex (usually $0.6-0.7 \mathrm{ml}$ ) to give a total settled volume of 0.8 to $0.9 \mathrm{ml}$. The column is finally washed with $\mathrm{NaCl}-\mathrm{NaHCO}_{3}$ $(0.5 \mathrm{ml})$. In preparing the column and analysis all solutions must be added slowly $(10-15 \mathrm{~s}$ per $0.5 \mathrm{ml})$ with minimal disturbance of the column. Columns are conveniently prepared after the addition of saturating iron solution to serum samples, and 
should be used within one and a half hours of preparation.

\section{PROCEDURE}

Saturating iron solution $(0.1 \mathrm{ml})$ is added to serum $(0.5 \mathrm{ml})$ and the mixture left to stand for 30 minutes. The treated serum $(0.5 \mathrm{ml})$ is transferred to a DEAE-Sephadex column and all the eluate is collected in a clean dry tube. When the last trace of serum disappears into the column five successive portions of $\mathrm{NaCl}-\mathrm{NaHCO}_{3}$ (each $0.5 \mathrm{ml}$ ) are added in the same way. It is convenient to run 10-12 columns together, but each portion of eluant should be added as soon as the surface of the column is exposed. The recommended columns flow at a suitable rate, which should not be increased because 'tailing' is likely to follow.

Serum iron is measured by applying serum $(0.5 \mathrm{ml})$ directly to a column.

Standard tubes contain standard iron solution $(1 \mathrm{ml} ; 0.02 \mu \mathrm{mol})$ and water $(2 \mathrm{ml})$. The 'blank' solution contains water $(3 \mathrm{ml})$. There is no advantage in running a 'blank' column with $6 \times 0.5 \mathrm{ml}$ $\mathrm{NaCl}-\mathrm{NaHCO}_{3}$ because the column removes any iron present in the salt solution. The UIBC counting standards contain radioactive saturating iron solution $(0.05 \mathrm{ml})$ and water $(2.95 \mathrm{ml})$. All counts are made to a standard error less than $1 \%$.

Ferrozine solution $(0.1 \mathrm{ml})$ is added to all tubes at least $15 \mathrm{~min}$ before the measurement of absorbance at 562 to $565 \mathrm{~nm}$. The complex is stable for several days. If the DEAE-Sephadex eluate appears significantly coloured (it is usually tinted very pale pink by $\mathrm{Fe}_{2}$-transferrin, but this should not be confused with the stronger colour given by haemoglobin) it is transferred to the cuvette and the spectrophotometer is set to zero before the addition of ferrozine.

CALCULATIONS

If the net absorbances of standard and unknown are $E_{s}$ and $E_{u}$, then serum $F e(\mu \mathrm{mol} / \mathrm{l})=\frac{E_{u}}{E_{s}} \times 40$ and TIBC $(\mu \mathrm{mol} / \mathrm{l})=\frac{E_{u}}{E_{s}} \times 48$. If standard and unknown give $C_{c}$ and $C_{u}$ counts/min and the absorbance of the counting standard is $E_{c}$, then $\operatorname{UIBC}(\mu \mathrm{mol} / \mathrm{l})=\frac{\mathrm{C}_{\mathrm{u}}}{\mathrm{C}_{\mathrm{c}}} \times \frac{\mathrm{E}_{\mathrm{c}}}{\mathrm{E}_{\mathrm{s}}} \times 48$.

\section{Validation Studies}

Ramsay (1973) used ion exchange and gel filtration to show that the iron measured in the magnesium carbonate method (Ramsay, 1957) and that of Nielsen (1968) included $1-11 \%$ of non-transferrin iron. Using ${ }^{59} \mathrm{Fe}$, similar tests have been applied to the new method. Preliminary work showed that the results are not affected by the substitution of NaCl-NaHCO${ }_{3}$ for the $\mathrm{NaCl}$-tris- $\mathrm{HCl}$ buffer previously used or by the change in the ion exchange technique. Electrophoretic analysis has confirmed that the new technique removes albumin completely from serum. Rechromatography of the DEAESephadex eluate on a fresh column indicates the completeness of recovery of the iron fraction sought. Gel filtration of the DEAE-Sephadex eluate on Sephadex G-150 is conducted by elution with $\mathrm{NaCl}-\mathrm{NaHCO}_{3}$ in acrylic resin columns $30 \stackrel{\infty}{\infty}$ $\mathrm{cm} \times 4 \mathrm{~cm}^{2}$ (Wright Scientific Ltd), run by up- i

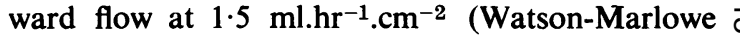
pump, type MHRE22). At the end of each run residual iron is eluted by passage of CDS $(5 \mu \mathrm{mol}$ in $1 \mathrm{ml} \mathrm{NaCl}-\mathrm{NaHCO}_{3}$ ), a procedure shown to be as effective as the citric acid formerly used. This technique is used to show how much of the iron is present in the molecular weight range corresponding approximately to transferrin.

The saturation of transferrin in the $\operatorname{DEAE}_{\Omega} \overrightarrow{0}$ Sephadex eluate is determined by using the observa tion of Bates and Schlabach (1973) that the nitrilos. triacetate (NTA) complex of $\mathrm{Fe}^{3+}$ reacts rapidfy with transferrin. A non-radioactive DEAE-Sephadex eluate is treated with $0.05 \mathrm{ml}{ }^{59} \mathrm{Fe}-\mathrm{NTA}$ (containing $0.02 \mu \mathrm{mol} \mathrm{Fe}{ }^{3+}$ and $0.05 \mu \mathrm{mol}$ NTA) and analysed on Sephadex G-150. The proportion of the total radioactivity found in the fractions containing transferrin allows the degree of unsaturation of the transferrin in the original DEAE-Sephadex eluate to be calculated. Control experiments showed that the results were not falsified by the removal of iron from transferrin by unchelated nitrilotriacetate.

\section{Results}

PRELIMINARY EXPERIMENTS

The complete elution of native transferrin-bound $\frac{D}{O}$ iron from DEAE-Sephadex-CDS was demonstrated by the chromatography of serum from a rat three $N$ and a half $\mathrm{hr}$ after the subcutaneous injection of $\mathrm{N}$ $4 \mu \mathrm{Ci}{ }^{59} \mathrm{Fe}$-citrate. In one experiment the eluate ${ }_{N}$ $(3 \mathrm{ml})$ gave 4130 counts $/ \mathrm{min}$, while $0.5 \mathrm{ml}$ serum diluted to $3 \mathrm{ml}$ gave 4160 counts $/ \mathrm{min}$. In four experiments the difference between diluted and chromatographed serum was between $-2 \%$ and $\Phi$ $+1 \%$. Gel filtration of the same sera on Sephadex G-150 gave recoveries $>98.5 \%$ in fractions which peaked at $0.54-0.58$ of the column volume. These recoveries were not altered by prior passage through DEAE-Sephadex. 
The apparent TIBC found after treating a normal human serum with increasing quantities of iron is shown in the figure. The chromatographic technique clearly copes with a large excess of iron. Gel filtration of the first of the apparently saturated samples after treatment with ${ }^{59} \mathrm{Fe}-\mathrm{NTA}$ showed it to be $99.8 \%$ saturated, whereas similar treatment of one of the earlier samples gave the expected level of about $80 \%$ saturation.

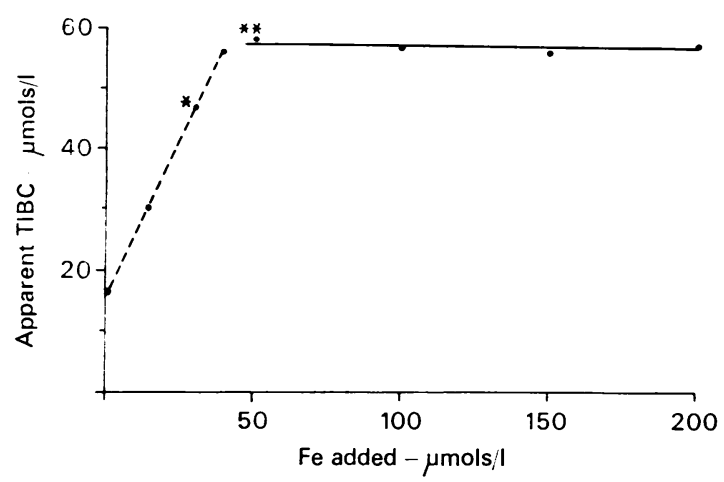

Fig Apparent total iron-binding capacity found after the addition of increasing amounts of iron to serum.

Tested with ${ }^{59} \mathrm{Fe}-N T A$ for saturation of transferrin, two additional samples gave the following results: $* 80 \%, * * 99.8 \%$

Exposure of serum and transferrin to the recommended excess of saturating iron for varying periods indicated that more than $95 \%$ of the final uptake was achieved within five minutes, but that complete saturation took place more slowly with purified transferrin. In one set of experiments two sera after 20 min gave apparent TIBC values $99.8 \%$ and $100 \%$ of those found after 60 minutes. For two transferrin solutions the corresponding figures were 98.8 and $98.3 \%$. The small difference, which was repeatedly confirmed, is of practical significance in relation to the precise evaluation of $\epsilon^{\prime}$.

Table I shows that the results are not affected by moderate concentrations of ferritin or Imferon. Imferon eluted from DEAE-Sephadex decomposes slowly in the ferrozine reagent, and the iron estimations should therefore be completed within 30 minutes. The effect of varying concentrations of haemoglobin is also shown, together with the spectrophotometric compensation for the error which affects the results when the concentration exceeds $30 \mathrm{mg} / 100 \mathrm{ml}$.

A comparison of serum iron determinations made on seven horse and five human sera by the new method and that recommended by the International

\begin{tabular}{lcll}
\hline Experiment & Fe added & Serum Fe & TIBC \\
\hline Haemoglobin & 0 & $35 \cdot 2$ & $52 \cdot 8$ \\
& 18 & $36 \cdot 6$ & $53 \cdot 2$ \\
& 36 & $41 \cdot 2$ & $57 \cdot 5$ \\
& 54 & $45 \cdot 4$ & $62 \cdot 2$ \\
Ferritin & 54 & $34 \cdot 8^{2}$ & $53 \cdot 4^{2}$ \\
& 0 & $22 \cdot 2$ & $46 \cdot 3$ \\
Imferon & 17 & $22 \cdot 4$ & $46 \cdot 5$ \\
& 0 & $13 \cdot 0$ & $40 \cdot 0$ \\
& 17 & $14 \cdot 2$ & $40 \cdot 2$ \\
\hline
\end{tabular}

Table I Effect of haemoglobin, ferritin, and imferon on serum $\mathrm{Fe}$ and TIBC ${ }^{1}$

${ }^{1}$ All figures in $\mu \mathrm{mol} / 1 \mathrm{Fe}$

${ }^{2}$ Spectrophotometer set to zero with sample in cuvette before addition of ferrozine

Committee for Standardization in Haematology (1971) gave a correlation coefficient $r=0.984$. The mean by the new method was $0.54 \mu \mathrm{mol} / 1$ higher. This difference probably represents error introduced by ignoring non-specific absorbance in the DEAESephadex eluate, because it was not seen in samples selected for freedom from haemolysis (see table III)

IRON-BINDING CAPACITY AND VALIDATION

Table II shows results obtained by applying the procedure and the validation tests to normal human and horse sera. Neither rechromatography on DEAE-Sephadex-CDS nor gel filtration on Sephadex G-150 removed significant amounts of iron from the radioactive eluate, while failure of the nonradioactive eluate to take up iron from ${ }^{59} \mathrm{Fe}-\mathrm{NTA}$ indicated complete saturation of transferrin.

\begin{tabular}{|c|c|c|}
\hline & Horse Serum & Human Serum \\
\hline $\begin{array}{l}\text { Serum Fe }(\mu \mathrm{mol} / \mathrm{l}) \\
\text { TIBC }(\mu \mathrm{mol} / \mathrm{l})\end{array}$ & $\begin{array}{l}29 \cdot 7 \\
57 \cdot 9\end{array}$ & $\begin{array}{l}13 \cdot 2 \\
52 \cdot 5\end{array}$ \\
\hline Transferrin saturation by & & \\
\hline${ }^{50} \mathrm{Fe}-\mathrm{NTA}(\%)$ & $99 \cdot 8$ & 100 \\
\hline $\mathrm{UIBC}(\mu \mathrm{mol} / \mathrm{l})$ & $28 \cdot 0$ & 37.9 \\
\hline $\begin{array}{l}{ }^{59} \mathrm{Fe} \text { recovered in DEAE } \\
\text { chromatography }(\%)\end{array}$ & 100 & 98 \\
\hline $\begin{array}{l}{ }^{59} \mathrm{Fe} \text {-eluted from G-150 in } \\
\text { transferrin molecular weight range } \\
(\%)\end{array}$ & 98 & 99 \\
\hline
\end{tabular}

Table II Validation of serum iron-binding capacity assays by the procedures described in the text

Table III summarizes comparisons between the new method and the $\mathrm{MgCO}_{3}$ method, with the addition of ion exchange and gel filtration tests on the $\mathrm{MgCO}_{3}$ supernatant (Ramsay, 1973). The new method gives lower results than $\mathrm{MgCO}_{3}$, but agreement is better after a correction is made for non-transferrin iron in the $\mathrm{MgCO}_{3}$ supernatants. The quality zontrol serum (Wellcome Two Assayed) 


\begin{tabular}{|c|c|c|c|c|c|c|c|}
\hline \multirow[t]{2}{*}{ Specimen } & \multirow[t]{2}{*}{ Method } & \multirow[t]{2}{*}{ Serum Fe } & \multirow[t]{2}{*}{$T I B C$} & \multirow{2}{*}{$\begin{array}{l}T I B C \\
\text { after } D E A E\end{array}$} & \multirow[t]{2}{*}{$U I B C$} & \multicolumn{2}{|l|}{$U I B C$} \\
\hline & & & & & & After $D E A E$ & After $G-150$ \\
\hline $\begin{array}{l}\text { Horse, } \\
\text { fresh }\end{array}$ & $\begin{array}{l}1 \\
2\end{array}$ & $\begin{array}{l}39 \cdot 7 \\
40 \cdot 5\end{array}$ & $69 \cdot 1$ & $\begin{array}{l}60 \cdot 4 \\
61 \cdot 2\end{array}$ & $30 \cdot 4$ & $\begin{array}{l}23 \cdot 4 \\
22 \cdot 2\end{array}$ & - \\
\hline $\begin{array}{l}\text { Horse, } \\
\text { frozen, }\end{array}$ & $\begin{array}{l}1 \\
2\end{array}$ & $\begin{array}{l}25 \cdot 3 \\
25 \cdot 1\end{array}$ & $74 \cdot 0$ & $\begin{array}{l}71 \cdot 2 \\
67 \cdot 7\end{array}$ & $46 \cdot 0$ & $\begin{array}{l}45 \cdot 3 \\
42 \cdot 3\end{array}$ & $45 \cdot 0$ \\
\hline $\begin{array}{l}\text { Horse, }{ }^{1} \\
\text { lyophilized }\end{array}$ & $\begin{array}{l}1 \\
2\end{array}$ & $\begin{array}{l}23 \cdot 6 \\
21 \cdot 8\end{array}$ & $60 \cdot 8$ & $\begin{array}{l}50.0 \\
48.0\end{array}$ & $36 \cdot 5$ & $\begin{array}{l}26 \cdot 3 \\
26 \cdot 1\end{array}$ & $26 \cdot 0$ \\
\hline $\begin{array}{l}\text { Human, } \\
\text { fresh }\end{array}$ & $\begin{array}{l}1 \\
2\end{array}$ & $\begin{array}{l}24 \cdot 1 \\
24 \cdot 4\end{array}$ & $63 \cdot 7$ & $\begin{array}{l}61 \cdot 5 \\
59 \cdot 8\end{array}$ & $40 \cdot 6$ & $\begin{array}{l}39 \cdot 2 \\
36 \cdot 6\end{array}$ & $38 \cdot 2$ \\
\hline $\begin{array}{l}\text { Human, } \\
\text { fresh }\end{array}$ & $\begin{array}{l}1 \\
2\end{array}$ & $\begin{array}{l}23 \cdot 2 \\
22 \cdot 8\end{array}$ & $57 \cdot 9$ & $\begin{array}{l}54.5 \\
53 \cdot 6\end{array}$ & $34 \cdot 2$ & $\begin{array}{l}32 \cdot 5 \\
31 \cdot 6\end{array}$ & $32 \cdot 2$ \\
\hline
\end{tabular}

Table III Analyses ( $\mu$ mol/l) of human and horse serum by (I) $\mathrm{MgCO}_{3}$ method with screening of results by DEAE-Sephadex and Sephadex G-150 (Ramsay, 1973) and (2) the method now described

'Wellcomtrol Two Assayed; manufacturer's values: serum Fe 24.0, TIBC $\left(\mathrm{MgCO}_{3}\right) 57 \cdot 3 \mu \mathrm{mol} / 1$

shows this difference clearly. This material gave highly reproducible results when analysed on four separate occasions (table IV). Validation experiments on the first bottle analysed gave satisfactory results. In particular, the ${ }^{59} \mathrm{Fe}-\mathrm{NTA}$ test indicated $99.6 \%$ saturation, giving further evidence that the original $\mathrm{MgCO}_{3}$ results are too high.

\begin{tabular}{llll}
\hline Bottle & Serum Fe & TIBC & UIBC \\
\hline 1 & $21 \cdot 8$ & $48 \cdot 0$ & $26 \cdot 1$ \\
2 & $22 \cdot 3$ & $48 \cdot 7$ & $26 \cdot 6$ \\
3 & $23 \cdot 0$ & $46 \cdot 9$ & $24 \cdot 6$ \\
4 & $22 \cdot 6$ & $47 \cdot 6$ & $25 \cdot 1$ \\
\hline
\end{tabular}

Table IV Serum iron, total and unsaturated iron-binding capacity ( $\mu \mathrm{mol} / \mathrm{l}$ ) on four bottles from the same batch of Wellcomtrol Two assayed control system (see Table III) ${ }^{1}$

${ }^{1}$ Bottles were opened singly at intervals over ten weeks. Validation tests on samples from bottle 1 gave satisfactory results including $99.6 \%$ saturation of transferrin by the iron tartrate reagent.

STORAGE AND PRESERVATION

Storage of fresh serum up to two weeks at 4 does not affect the results.
Aliquots of the horse serum used for the experiments quoted in table II were measured into vials 은 which were weighed, shell frozen, lyophilized, and capped. After storage for varying times at different $T$ temperatures the samples were reconstituted to the $\frac{\mathbb{O}}{\mathrm{O}}$ original weight with distilled water. Other serum aliquots were stored frozen at -50 . Analysis (table $₹$ V) showed that neither frozen nor lyophilized $\overrightarrow{0}$ specimens were affected by storage for up to tw 8 or months. All the results afford a good example the high reproducibility of the method.

PURIFIED TRANSFERRIN

Preliminary work on iron-free human transferrin (Behringwerke) confirmed its low iron content. Electrophoresis showed only a trace of $\beta_{2}$-globulin, and although the conditions used would not have disclosed the presence of haemopexin, Bates and Schlabach (1973) found very little of this impurity in the same material. For the evaluation of $\epsilon^{\prime}$, solutions $(1.5-3 \mathrm{mg} / \mathrm{ml})$ in $\mathrm{NaCl}-\mathrm{NaHCO}_{3}$ were used for the measurement of TIBC, allowing $60 \stackrel{3}{3}$ min for saturation with iron. $E_{280}$ was measured on separate aliquots passed without iron treatment through DEAE-Sephadex without CDS, because

\begin{tabular}{|c|c|c|c|c|c|}
\hline Type of Specimen & Weeks of Storage & Temperature $\left(C^{\circ}\right)$ & Serum Fe & $T I B C$ & $U I B C$ \\
\hline Fresh & - & - & $29 \cdot 7$ & $57 \cdot 9$ & $28 \cdot 0$ \\
\hline Frozen & $\begin{array}{r}1 \\
4 \\
8 \\
10\end{array}$ & $\begin{array}{l}-50 \\
-50 \\
-50 \\
-50\end{array}$ & $\begin{array}{l}30 \cdot 2 \\
28 \cdot 8 \\
28 \cdot 9 \\
29 \cdot 4\end{array}$ & $\begin{array}{l}57 \cdot 1 \\
56 \cdot 6 \\
56 \cdot 0 \\
56 \cdot 5\end{array}$ & $\begin{array}{l}28 \cdot 1 \\
28 \cdot 6 \\
27 \cdot 2 \\
27 \cdot 3\end{array}$ \\
\hline \multirow[t]{2}{*}{ Lyophilized } & $\begin{array}{r}1 \\
4 \\
8 \\
10\end{array}$ & $\begin{array}{r}-50 \\
22 \\
22 \\
4\end{array}$ & $\begin{array}{l}30 \cdot 2 \\
29 \cdot 8 \\
30 \cdot 2 \\
30 \cdot 2\end{array}$ & $\begin{array}{l}56.9 \\
56.7 \\
56.2 \\
57.4\end{array}$ & $\begin{array}{l}27 \cdot 9 \\
28 \cdot 2 \\
26 \cdot 0 \\
26 \cdot 9\end{array}$ \\
\hline & & $\begin{array}{r}\text { Mean } \\
\text { SD }\end{array}$ & $\begin{array}{r}29.7 \\
\pm 0.6\end{array}$ & $\begin{array}{r}57.0 \\
\pm 0.5\end{array}$ & $\begin{array}{l}27 \cdot 6 \\
\pm 0.8\end{array}$ \\
\hline
\end{tabular}

Table V Effects of freezing, lyophilization, and storage of one lot of horse serum on serum Fe, total and unsaturated iron-binding capacity ( $\mu \mathrm{mol} / \mathrm{l})^{1}$

${ }^{1}$ The results of validation tests on the analyses on this fresh serum are reported in table II. 


\begin{tabular}{|c|c|c|c|}
\hline & \multicolumn{3}{|c|}{ Transferrin Preparation } \\
\hline & Sigma & Behringwerke & Behringwerke (Standard) \\
\hline $\begin{array}{l}\text { TIBC }(\mu \mathrm{mol} / \mathrm{l}) \\
\text { A, serum }+ \text { transferrin } \\
\text { B, serum } \\
\text { C, transferrin } \\
\text { Transferrin recovered }(A-B) \\
\text { Transferrin expected }{ }^{1}\end{array}$ & $\begin{array}{l}92 \cdot 1 \\
55 \cdot 2 \\
37 \cdot 0 \\
36 \cdot 9 \\
36 \cdot 4\end{array}$ & $\begin{array}{l}79 \cdot 1 \\
52 \cdot 5 \\
26 \cdot 8 \\
26 \cdot 6 \\
26 \cdot 9\end{array}$ & $\begin{array}{l}91 \cdot 3 \\
48 \cdot 7 \\
44 \cdot 4 \\
42 \cdot 6 \\
44 \cdot 0\end{array}$ \\
\hline$\epsilon^{\prime 2}$ & 88300 & 89200 & 86400 \\
\hline
\end{tabular}

Table VI Use of purified transferrin as reference material in iron-binding capacity assays

${ }^{1}$ Calculated from observed absorbance of solution $\mathbf{C}$ and mean $\epsilon^{\prime}$ found for each transferrin type (see text)

${ }^{2}$ Calculated from observed absorbance and TIBC of solution $\mathrm{C}$ in these experiments

this compound absorbs strongly at $280 \mathrm{~nm}$ and any breakthrough would vitiate the results. In general, analyses of pure transferrin require more care than serum, perhaps because the total amount of protein passing through the column is very small. In 20 experiments the mean value of $\epsilon^{\prime}$ was 88800 (SD \pm 900 , range $87200-90600$ ). Six measurements on human transferrin (Sigma), which appeared to be of comparable purity, gave $\epsilon^{\prime}=89800$ $(\mathrm{SD} \pm 1000$, range $88300-91000)$. Neither preparation gave different results after preliminary passage through either a large column $(60 \mathrm{~cm} \times$ $4 \mathrm{~cm}^{2}$ ) of Sephadex G-150 in $\mathrm{NaCl}-\mathrm{NaHCO}_{3}$ or a smaller column of Sephadex G-25 in $\mathrm{NaC1O}_{4}$ (Price and Gibson, 1972), Chelating agents which interfere with the method are thus absent. but complete freedom from chelating agents is not proved, because the analytical results were not affected by EDTA equivalent to approximately $25 \%$ of total iron-binding capacity. In two experiments on immunological standard transferrin (Behringwerke) $\epsilon^{\prime}$ was 88200 and 86400 . In several experiments tests with ${ }^{59} \mathrm{Fe}-\mathrm{NTA}$ confirmed the full saturation of transferrin.

Although uncertainty in the value of $\epsilon$ makes it impossible to determine the precise accuracy of these highly reproducible values of $\epsilon^{\prime}$, the transferrin preparations studied should be suitable as reference materials. Appropriate control analyses might include a check evaluation of $\epsilon^{\prime}$ and the assay of transferrin added to serum, and should ideally be accompanied by validation tests on the serum analysis. A possible procedure is outlined below:

1 Prepare a stock transferrin solution from a suitably pure sample by dissolving $16-20 \mathrm{mg}$ in $1 \mathrm{ml} \mathrm{NaCl}-\mathrm{NaHCO}_{3}$.

2 Use this solution to prepare the following: A, serum $(2.5 \mathrm{ml})+$ transferrin $(0.25 \mathrm{ml}) ; \mathrm{B}$, serum $(2.5 \mathrm{ml})+\mathrm{NaCl}-\mathrm{NaHCO}_{3}(0.25 \mathrm{ml}) ; \mathrm{C}, \mathrm{NaCl}-$ $\mathrm{NaHCO}_{3}(4.0 \mathrm{ml})+$ transferrin $(0.40 \mathrm{ml})$.

3 (a) Measure TIBC on solutions A, B, C, by the method described. (b) Measure $E_{280}$ after passage of solution $\mathrm{C}(0.5 \mathrm{ml})$ through DEAE-Sephadex (without CDS) with $\mathrm{NaCl}-\mathrm{NaHCO}_{3}(5 \times 0.5 \mathrm{ml})$.

4 (a) Confirm that solution $\mathrm{C}$ gives a satisfactory $\epsilon^{\prime}$ value. (b) Confirm that TIBC $_{A}-$ TIBC $_{B}=$ TIBCC.

When immunological standard transferrin (Behringwerke) is used, at least $3 \times 1 \mathrm{mg}$ ampoules are required. Solution $A$ and two lots of solution $C$ are prepared by direct addition of serum or $\mathrm{NaCl}-$ $\mathrm{NaHCO}_{3}$ to the opened ampoules. It must be assumed that ampoules contain identical quantities of transferrin.

Table VI gives one example of this procedure applied to each of the three preparations studied. The $\epsilon^{\prime}$ values and the recoveries of transferrin judged by TIBC seem highly satisfactory.

\section{Discussion}

The complete removal of albumin and associated pigments by the chromatographic step is a major advantage, because the analysis is improved in speed and precision by the omission of protein precipitation. Columns can be prepared and used more quickly than might be expected, and a dozen specimens can be processed in about 45 minutes less time than is required for the $\mathrm{MgCO}_{3}$ method. Although DEAE-Sephadex has some capacity for removing excess iron added to serum (Ramsay, 1973), the columns now used are very small. Preliminary studies showed that the iron-scavenging properties of CDS ensure a clean and complete separation of transferrin-bound iron from that less stably complexed. The column unfortunately has no clearing effect on lipaemic serum or on the turbidities found in some quality control sera, and these can only be handled by protein precipitation. Jaundiced serum, however, can be dealt with by spectrophotometric compensation for non-specific absorbance as recommended for haemolysed samples.

The experimental $\epsilon^{\prime}$ values around 89000 are within $1 \%$ of a figure calculated from the data of 
Roberts et al (1966), who used very different methods. On the other hand, they are $5 \%$ higher than the lowest figure for the molar absorptivity of transferrin, obtained by assuming a molecular weight of 77000 and $E^{1{ }^{\circ}}{ }_{1} \cdot \mathrm{cm}=10.9$. Several factors may contribute to the discrepancy, including traces of residual impurity in transferrin preparations, occasional low values for TIBC, error in either the molecular weight or $\mathrm{E}^{1{ }^{\circ}}{ }_{1} \mathrm{~cm}$, or error in other absorbance measurements. The small possible margin of error in $\epsilon^{\prime}$ should not prove an obstacle to the practical use of available transferrin preparations as reference materials. There seems no reason why immunological standards should not be calibrated in the same way, and it would be a logical advance to put all kinds of transferrin measurement on a common molar reference base.

While this work is personal, the author is indebted to his colleagues on the Iron Panel, ICSH, for much stimulating discussion. Thanks are also due to R. W. Brown for skilled technical assistance, to the Agricultural Research Council, which gave the radioactive counting equipment to the Faculty of Veterinary Medicine, University of Edinburgh, and to the Earl of Moray Endowment, University of Edinburgh, for a grant with which supplies of purified transferrin were purchased.

\section{References}

Bates, G. W., and Schlabach, M. R. (1973). The reaction of ferric salts with transferrin. J. biol. Chem., 248, 3228-3232.

Betts, C. A., and Stuart, B. (1973). Determination of serum total iron binding capacity. J. clin. Path., 26, 457

Bothwell, T. H., Conrad, M. E., Cook, J. D., Crosby, W. H., Fielding, J., Hallberg, L., Izak, G., Layrisse, M., and Ramsay, W. N. M. (1972). Studies on the standardization of serum iron and iron binding capacity assays. In Modern Concepts in Hematology edited by G. Izak and S. M. Lewis, pp. 67-160. Academic Press New York and London.

Carter, P. (1971). Spectrophotometric determination of serum iron at the submicrogram level with a new reagent (ferrozine). $\mathcal{S}$ 3(2-pyridyl)-5,6-bis(4-phenyl sulphonic acid)-1,2,4-triazine, disodium salt trihydrate. Analyt. Biochem., 40, 450-458.

Charlwood, P. A. (1971). Differential sedimentation-velocity and gel-filtration measurements on human apotransferrin and iron-transferrin. Biochem. J., 125, 1019-1026.

Dixon. P. (1973). Routine clinical measurements of transferrin in human serum. Ann. clin. Biochem., 10, 127-131.

Fraser, C. G. (1973). Problems in the determination of serum total iron binding capacity. J. clin. Path., 26, 457-458.

Greene, F. C., and Feeney, R. E. (1968). Physical evidence for transferrins as single polypeptide chains. Biochemistry, 7, 1366-1371. Z

van der Heul, C., van Eijk, H. G., Wiltink, W. F., and Leijnse, B. $\omega$ (1972). The binding of iron to transferrin and to other serum components at different degrees of saturation with iron. Clin. $\frac{\Omega}{0}$ chim. Acta, 38, 347-353.

International Committee for Standardization in Hematology (1971). N Proposed recommendations for measurement of serum iron in human blood. Brit. J. Haemat., 20, 451-453.

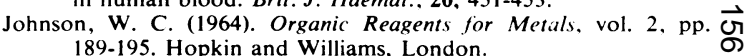

Leggate, J., and Crooks, A. E. (1972). Problems in quality control 응 in determinations of serum total iron-binding capacity by the magnesium carbonate method. J. clin. Path., 25, 905-906.

Mann, K. G., Fish, W. W., Cox, A. C., and Tanford, C. (1970). T Single-chain nature of human serum transferrin. Biochemistry, 9. 1348-1354

Nielsen, 1. (1968). A gel filtration method for determining total iron binding capacity in serum. Z. klin. Chem., 6, 103-105.

Palmour, R. M., and Sutton, H. E. (1971). Vertebrate transferrins, molecular weights, chemical compositions, and iron binding $\bullet$ studies. Biochemistry, 10, 4026-4032.

Price, E. M., and Gibson, J. F (1972). A reinterpretation of bicte. bonate-free ferric transferrin EPR spectra. Biochem. Bioph Res. Commun., 46, 646-651.

Ramsay, W. N. M. (1957). The determination of total iron bindia capacity of serum. Clin. chim. Acta, 2, 221-226.

Ramsay, W. N. M. (1973). The measurement of serum transferrin by iron-binding capacity. J. clin. Path., 26, 691-696.

Rand, R. N. (1969). Practical spectrophotometric standards. Clin. Chem., 15, 839-863.

Roberts, R. C., Makey, D. G., and Seal, U. S. (1966). Human trans- $\overline{\bar{O}}$ ferrin: molecular weight and sedimentation properties. $J$. biol. Chem., 241, 4907-4913.

Stookey, L. L. (1970). Ferrozine, a new spectrophotometric reagent for iron. Analyt. Chem., 42, 779-782. 